\title{
Monitoring changes in pastoral resources in eastern Sudan: A synthesis of remote sensing and local knowledge
}

\author{
Hussein M Sulieman $^{1 *}$ and Abdel Ghaffar M Ahmed²
}

\begin{abstract}
The pastoral resources in eastern Sudan are changing under the combined impact of increasing anthropogenic activities such as clearance of natural vegetation and the effect of state policies that favour crop farming against pastoralism. Remotely sensed data are used to detect spatial and temporal changes from 1979 to 2009 in the land use/land cover (LULC) across three study sites. Areas of natural vegetation have been reduced from $26.1 \%$ in 1979 to $12.6 \%$ in 1999 and further to $9.4 \%$ in 2007. The majority of this reduction went into agricultural land. Local knowledge of pastoralists on their perceived changes in plant species is obtained. Major LULC trends are progressive degradation and loss of grazing areas, loss of biodiversity and depletion of other ecological support provided by natural vegetation. Declining rainfall, land clearance due to agricultural expansion, overgrazing and herbicide applications by crop farmers are identified as underlying forces changing plant species in the region. The study revealed that pastoralists have considerable knowledge and experience in dealing with degradation and climate variability. However, pastoralists are marginalized in decisions concerning expansion of large-scale agriculture at the expense of pasture land. Their lack of education and other basic services restricts the pastoralists' potential to adapt to the new situation.
\end{abstract}

Keywords: Transhumance pastoralism; Land use/land cover analysis; Change in plant species; State policy; Gadarif; Sudan

\section{Background}

Livestock has consistently played a central role in the economy and welfare of Sudan. Although in recent years oil production has become the dominant feature of the country's political economy, livestock and livestock products continued to contribute approximately $20 \%$ of Sudan's annual Gross Domestic Product (GDP) and are the most important contributor to agricultural sector GDP, when compared to crop farming (Fahey 2007). The livestock producers are pastoralists, agro-pastoralists or sedentary farmers who maintain herds and also engage in crop production. In Gadarif State (eastern Sudan), livestock production is dominated by pastoral and agro-pastoral traditional systems that have evolved in response to the region's

\footnotetext{
* Correspondence: hmsulieman@yahoo.com

${ }^{1}$ Centre for Remote Sensing and Geographical Information Systems, Faculty of Agricultural and Environmental Sciences, University of Gadarif, P.O. Box 449, 32211 Gadarif, Sudan

Full list of author information is available at the end of the article
}

diverse environment. In recent decades, pastoralism has been in decline because of threats posed by rapid encroachment of mechanized rain-fed agriculture, human population growth and other human activities that force extensive livestock production to shift to areas of increasing marginal productivity (Shazali and Ahmed 1999; Sulieman and Elagib 2012).

Manger (2001), Ahmed (2009), and Shazali and Ahmed (1999) stated that increasing numbers of pastoralists in Gadarif region are losing their livestock due to shrinking grazing areas, and pastoralists are forced to leave the sector altogether. However, it has been suggested that instead of attempting to settle pastoralists and transhumant populations in towns and villages, governments and policymakers at federal and state levels should seek to rehabilitate pastoral livelihoods through a combination of traditional and modern approaches to land and livestock management systems (Sulieman and Elagib 2012).

\section{它 Springer}


One of the major consequences of the rapid expansion of mechanized farming is the creation of inequality in land distribution resulting from the appropriation of land by a few influential elites. This creates intensive competition over land among different groups of users (Sulieman 2008). The process was institutionalized during the Anglo-Egyptian colonial period when the policy clearly stated that the rights of the cultivator should be considered as paramount to nomadic pastoralists (SCC 1944). Moreover, due to agricultural expansion, the region has become one of the deforestation hotspots in the African continent (Sulieman and Elagib 2012).

Local communities are always aware of the environmental changes taking place in their surroundings (Sulieman et al. 2012). This makes it essential to integrate scientific and local knowledge so that communities are able to fully realize their capacity to monitor and respond to the challenges of degradation and environmental change (Stringer and Reed 2007). Reed et al. (2008) noted that local knowledge was more holistic than many published indicator lists for monitoring rangelands. It encompasses vegetation, soil, livestock, wild animals and socio-economic indicators. Through their local knowledge, pastoralists have managed to adjust their strategies according to the rainfall pattern and avoid muddy soils and fly-infested pastures. By following cyclic and migratory strategies and other opportunistic husbandry practices, the nomads were able to prevent the extinction of their livestock herds and flocks and maintain the bio-diversity of the local breeds (Sidahmed 1996).

In order to make grazing practices sustainable, it is important to ascertain spatial distribution, monitor spatiotemporal changes and analyze the primary reasons that cause changes in grasslands (Feng et al. 2009). In situations of rapid and often unrecorded changes, observations of the Earth from space provide objective information of human utilization of the landscape (Lambin et al. 2003; Ruelland et al. 2010). However, data from satellite imagery will be more suitable for planning to address the problems emanating from issues such as land degradation if satellite data are integrated with local knowledge (Yiran et al. 2012).

Significant information gaps persist regarding the current situation of grazing resources in Gadarif State. Likewise, little is known about the current and prospective resilience of the ecosystem as a whole due to current land use/land cover (LULC) changes. Therefore, periodic monitoring of pastoral resource condition is essential to appreciate the prospects for pastoral enterprises without long-term deterioration in pastoral land conditions. Thus, our main objective is to examine how LULC changes affected grazing resources in Gadarif State, eastern Sudan.

Three specific approaches guide this study. First is the use of remote sensing techniques to obtain information on the spatial and temporal patterns of LULC changes and its impact on pastoral resources. Second is to investigate local knowledge of pastoralists and agro-pastoralists on how they perceive the changes taking place in grazing resources. The third approach is to examine the merits of integrating remote sensing techniques and local knowledge of pastoral and agro-pastoral groups in the area. The results will facilitate decision-making to mitigate pastoralists' vulnerability in Gadarif region.

\section{Study area}

Geographically, Gadarif State is located in eastern Sudan (Figure 1) with an area of approximately $78,000 \mathrm{~km}^{2}$. The mean temperature in Gadarif town is $29^{\circ} \mathrm{C}$, the mean maximum is $37^{\circ} \mathrm{C}$ and the mean minimum is $21^{\circ} \mathrm{C}$. May is the hottest month of the year. The area is characterized by a uni-modal rainfall season which primarily occurs from June to September. Annual rainfall in the area ranges from less than $300 \mathrm{~mm}$ in the north to more than $800 \mathrm{~mm}$ in the south. Vegetation cover plays a vital role in meeting the basic needs of the people and in supporting their herds. Thus, vegetation cover is subject not only to climatic variations but also to human activities such as clearing of natural vegetation for agricultural or energy purposes, overgrazing and brush fires (Sulieman 2008).

According to the 2008 census, the total population of Gadarif State is 1.34 million with an annual population growth rate of $4.7 \%$, higher than the national growth rate (CBS 2012).

Gadarif region is home to some of the largest mechanized rain-fed schemes in Sudan. This is mainly due to the fact that mean annual rainfall is sufficient to sustain such production, hence increasing land productivity as well as being able to feed the growing population. In total, the state has around 4.2 million ha of cultivable land at its disposal (MFC 2012). Much of this land was originally mixed savannah-woodland providing grazing lands for pastoralists and agro-pastoralists. However, there is a conspicuous shift from livestock production to crop farming (Sulieman 2008). The current land tenure system has created a situation of a few large-scale farmers and many small-scale farmers, as well as restricting livestock herders to the marginal areas of the state (Glover 2005). These processes have led pastoral groups towards rapid sedentarization, urbanization and the breakdown of their traditional livelihood system.

Three study sites were selected in order to represent the major pastoral resources in the region, i.e. summer dry season camping places along the river banks, the seasonal migration routes and the rainy season communal grazing land of Butana. The surveyed pastoralists in the study sites belong to the ethnic group of Lahaween. The Lahaween are an Arab pastoralist group. The movement of most Lahaween from Kordofan to Gadarif State was during the Mahdiyia period (1881 to 1898). Normally they breed a 


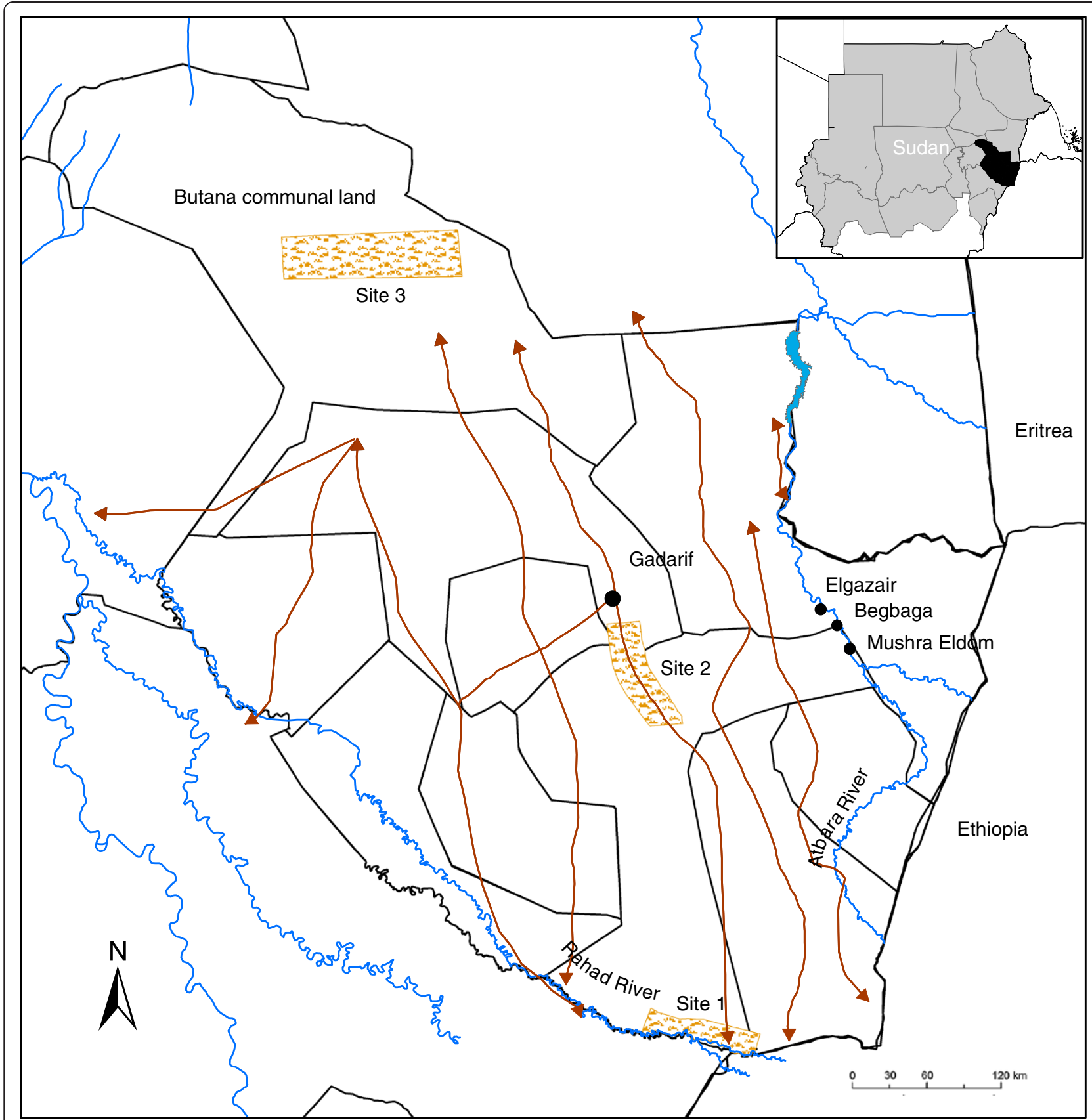

Figure 1 Map showing study area and location of study sites. Double-arrowhead lines are the livestock migration routes.

multi-stock herd of camels, goats and sheep (Tamador 2010). A few cultivate crops during the rainy season, mainly for subsistence.

\section{Site 1: summer dry season camping places along the rivers}

The two major rivers in the region are the Atbara along the eastern border of the state and Rahad along the southern part bordering Dinder National Park (Figure 1). The areas along both banks of the two rivers and its associated natural vegetation represent the most favourable summer camping areas for the majority of transhumant pastoralists in the region, where they pitch their camps and water their animals. Along the Atbara River, grazing activities are more confined to kerrib land which is a land terrain affected by gully erosion along both sides of the Atbara River. This type of land consists of a mass of gullies, with sandy soils in the gully bottoms and numerous fragments of calcium carbonate strewn over the slopes (Ahmed 1989). The bushy shrubs of kerrib areas offer a good forage resource especially for 
camels, sheep and goats. Nevertheless, the area is suffering from overgrazing which is more intense and visible near villages where palatable plant species have disappeared from the area (according to our field observations and the interviewed herders), woody vegetation is reduced to stunted stumps and a significant proportion of land is bare. Households belonging to these villages practice transhumance pastoralism. In the rainy season this part of the region becomes uninhabitable for animals, as clay soils turn into a sticky mass. Therefore, the pastoralists move their herds to the north by way of migration routes to find suitable pastures.

\section{Site 2: seasonal migration routes}

Transhumance, the seasonal movement of herds occurring between two points and following precise routes repeated each year, is practiced by large numbers of pastoralists in Gadarif State. As already noted, herders and their animals migrate to the northern parts of the state looking for pasture in the Butana following specified routes (Figure 1) starting with the rains, approximately from late June to late July, until it is certain that there is enough water in pools and seasonal watercourses on their routes. This movement involves a number of halts, varying from a couple of days to around two weeks, depending on water and grass availability. The southward journey back to summer dry season camping areas starts mid-September to early October and has to be done rapidly, since water and grass become scarcer. The herders cover this part with as few halts as possible (Table 1).

\section{Site 3: rainy season communal grazing land of Butana}

Historically, the Butana is known by pastoralists to be a very good pasture area due to its excellent vegetation cover. Woodland-savannah vegetation is also found in the area but is ultimately restricted to shallow depressions and khors (seasonal watercourse)/valleys because of comparatively favourable ground water conditions. However, it is only during the last decades that the Butana has been subject to severe overgrazing, due to the introduction of an open grazing system by the government.
In 1971, the 'General Grazing Area' was extended by the government over the entire Butana. The then government's socialist idea that state-owned lands, i.e. natural resources, should be accessible to everybody led to the abolishment of communally managed grazing areas, hence eliminating specific tribal rights over the resources of their homelands (Akhtar 1993). This allows any pastoral group from different parts of the surrounding region to enter and use the state-owned grazing areas during the rainy season.

\section{Methods}

\section{Data sets}

The study uses a combination of remote sensing data from the last four decades together with qualitative and quantitative social data based on interviews with pastoralists, in addition to field observations. The pastoralists' perceptions and values served not only as a means of verifying and assuring the remote sensing-based LULC analysis but also for providing insights on how these changes happened. Moreover, local communities provide information that is not detectable with the type of remote sensing data that has been used in this study, including changes in plant species.

\section{Satellite imagery}

The remote sensing approach involved multi-temporal LULC analysis for the three study sites (Figure 1). Site 1 is 65,401 ha, site 2 is 36,535 ha and site 3 is 71,577 ha. Cloudfree multi-sensor satellite imagery has been used to detect the multi-temporal LULC change (Table 2). All imageries were acquired at the beginning of the dry season so that the phenological stages of plant covers are not too different between dates. Moreover, this period, which follows the harvests, may be considered the best time of year for distinguishing the various LULC types. Table 3 shows major LULC classes existing in the study area. Determination of major LULC classes was based on field surveys and interviews with pastoralists and villagers across the three study sites. LULC classification was performed using the maximum likelihood algorithm. Due to unavailability of historical data, i.e. aerial photographs and maps, the accuracy of

\section{Table 1 General description of seasonal migration routes in Gadarif State}

\begin{tabular}{|c|c|c|c|c|c|}
\hline Route number & Route name & Width (m) & Length (km) & Number of rest places & Number of hafirs (man-made ponds) \\
\hline 1 & Eldareb Elaswad & 300 & 145 & 3 & 3 \\
\hline 2 & Simsim & 150 & 290 & 5 & 4 \\
\hline 3 & Um Trimby & 150 & 230 & 5 & 4 \\
\hline 4 & EsikaHadid & 150 & 66 & 2 & 2 \\
\hline 5 & Kerkora & 150 & 290 & 5 & 8 \\
\hline 6 & Elmagataa & 150 & 244 & 3 & 2 \\
\hline 7 & Shalia & 150 & 290 & 6 & 5 \\
\hline 8 & Elkhiry & 150 & 100 & 3 & 3 \\
\hline
\end{tabular}


Table 2 Characteristics of satellite imagery used for LULC analysis

\begin{tabular}{|c|c|c|c|c|}
\hline Satellite & Sensor & Path/row & Acquisition date & Spatial resolution $(\mathrm{m})$ \\
\hline Landsat 3 & MSS & $184 / 050$ & 23-11-1979 & 60 \\
\hline Landsat 3 & MSS & 184/051 & 23-11-1979 & 60 \\
\hline Landsat 4 & MSS & 171/051 & $12-12-1987$ & 60 \\
\hline Landsat 7 & ETM & $171 / 050$ & 06-12-1999 & 30 \\
\hline Landsat 7 & ETM & $171 / 051$ & 06-12-1999 & 30 \\
\hline Landsat 7 & ETM & $171 / 050$ & 08-10-2005 & 30 \\
\hline Landsat 7 & ETM & 171/051 & 22-03-2007 & 30 \\
\hline ASTER & Terra & $171 / 050$ & $17-01-2009$ & 15 \\
\hline
\end{tabular}

MSS Multispectral scanner system, ETM Enhanced thematic mapper.

each classification was assessed based on visual interpretation of unclassified images and later compared with classified images (Sulieman and Elagib 2012; Biro et al. 2011; Zheng et al. 1997) by means of commission and omission errors (Richards and Jia 2005). To allow multi-temporal comparisons, all images were re-sampled to a $30 \times 30 \mathrm{~m}$ pixel size using the nearest neighbour technique. The images were geo-referenced to obtain optimal superimposition and minimize geographical deviation. In order to quantify changes of certain LULC types during a certain time period, the calculation formula followed was:

$$
\text { LULCC }=((U 2-U 1) / U 1 \times T) 100 \%
$$

where LULCC is the change of a certain LULC type for a certain time period; $U 1$ and $U 2$ are the area of a certain LULC type at the beginning and the end of a time period, respectively; and $T$ is the time period. A positive value means that there is an increasing trend for a specific time period for an area of a certain LULC type; otherwise, a deceasing trend is occurring for the area assessed.

\section{Social survey}

Formal questionnaires were considered a main tool for collecting the required quantitative information from 50 selected transhumant pastoralists at three camping sites, i.e. Begbaga, Mushra Eldom and Elgazair (Figure 1), located along the western bank of the Atbara River. However, key informant group discussions were also conducted to gather other relevant qualitative information. Interviews were conducted during November and December 2011. Questionnaire interviews with pastoralists were designed to be broader to cover all range of information. Interviews included questions pertaining to personal characteristics of respondents; migratory patterns; information regarding changes in grazing resources, range species and water resources; and major problems facing pastoralism. Questions on climate and weather included herders' perception on long-term changes on major climatic variables such as rainfall pattern, temperature and winds. Questions were also posed about adaptation measures that have been followed by pastoralists and the constraints to adaptation. Reasons for plant species changes were also investigated. Other groups that have been interviewed included pastoralists' tribal leaders, members of the Herders' Union (an official body established by the government), and officials of the Range Department.

\section{Results}

\section{Spatial and temporal changes in pastoral lands}

The general patterns of LULC changes across the three study sites are shown in Figure 2. The maps depict changes in each of the main LULC classes during the study period. Main LULC classes in site 1 and site 2 are bare land, agricultural land and woodland savannah, while in site 3 major classes are bare land, grassland and shrub/tree cover. The natural vegetation cover (i.e. woodland savannah, grassland and shrub/tree cover) represents the grazing resource. The results showed that conversions were common among

Table 3 Description of major LULC classes defined in the study area

\begin{tabular}{ll}
\hline Class & Description \\
\hline Bare land & $\begin{array}{l}\text { Exposed non-vegetated areas formerly under cultivation and now abandoned due to degradation. This class also included } \\
\text { unsuitable eroded areas characterized by bare rocks and gravels }\end{array}$ \\
$\begin{array}{l}\text { Natural } \\
\text { vegetation }\end{array}$ & $\begin{array}{l}\text { In site } 1 \text { and site 2, primary and secondary natural forest and woodland savannah appeared on some abandoned agricultural land, } \\
\text { In site 3, there are two other distinct natural vegetation types, namely grassland cover, which is the dominant land cover in the } \\
\text { whole Butana area, and shrub/tree woodland cover confined to valleys, along watercourses and depressions }\end{array}$ \\
Agricultural & This class represented areas under rain-fed mechanized farming covered with residue or late-emerging grass species biomass. \\
land & Crops cultivated in this area include sorghum and sesame
\end{tabular}




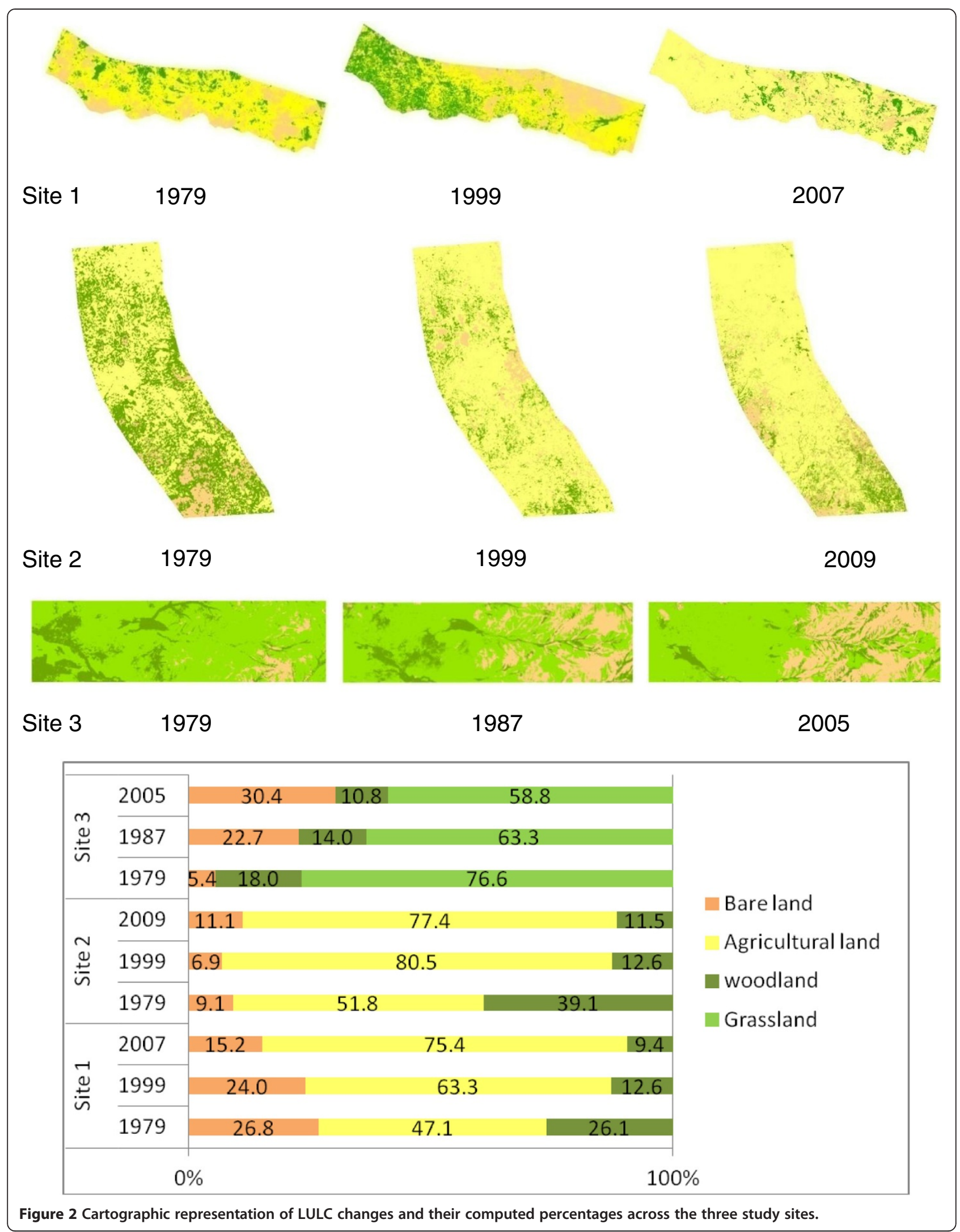


Table 4 Accuracy assessment of the LULC classes across the three study sites

\begin{tabular}{|c|c|c|c|c|c|c|c|}
\hline \multirow[t]{2}{*}{ Site } & \multirow[t]{2}{*}{ LULC class } & \multicolumn{6}{|l|}{ Error } \\
\hline & & Omis. & Comm. & Omis. & Comm. & Omis. & Comm. \\
\hline \multirow[t]{5}{*}{ Communal grazing land of Butana } & & 1979 & & 1987 & & 2005 & \\
\hline & Bare land & 8.82 & 5.00 & 9.03 & 6.45 & 5.56 & 2.78 \\
\hline & Grassland & 6.61 & 6.67 & 13.21 & 15.02 & 0.00 & 0.00 \\
\hline & Woodland savannah & 13.79 & 16.24 & 11.20 & 12.82 & 3.23 & 6.45 \\
\hline & Overall accuracy & 84.15 & & 79.78 & & 94.37 & \\
\hline \multirow[t]{5}{*}{ Seasonal migration routes } & & 1979 & & 1999 & & 2009 & \\
\hline & Bare land & 0.00 & 12.5 & 09.00 & 1.90 & 7.60 & 0.00 \\
\hline & Woodland savannah & 7.95 & 8.35 & 5.56 & 8.33 & 0.00 & 5.71 \\
\hline & Agricultural land & 12.82 & 0.00 & 4.79 & 11.00 & 2.98 & 5.88 \\
\hline & Overall accuracy & 88.22 & & 89.41 & & 93.16 & \\
\hline \multirow[t]{5}{*}{ Summer camping area } & & 1979 & & 1999 & & 2007 & \\
\hline & Bare land & 4.27 & 2.94 & 0.00 & & 5.41 & 2.70 \\
\hline & Woodland savannah & 2.90 & 2.86 & 2.95 & & 0.00 & 0.00 \\
\hline & Agricultural land & 8.33 & 2.18 & 6.51 & & 2.94 & 6.89 \\
\hline & Overall accuracy & 89.05 & & 92.69 & & 96.89 & \\
\hline
\end{tabular}

Omis omission error, Comm commission error.

various LULC types in the region. This converted acreage went into other LULC types, particularly into agricultural land.

On the Atbara and Rahad river banks, areas of natural vegetation have been reduced from $26.1 \%$ in 1979 to $12.6 \%$ in 1999 and further to $9.4 \%$ in 2007 . The majority of this reduction went into agricultural land which remains the dominant LULC in this site. Bare land which once represented around a quarter of the study site has been reduced to $15.2 \%$ in 2007 .

Along the seasonal migration routes, the area under natural vegetation cover dropped from $39.1 \%$ to $11.6 \%$ during the study period (1979 to 2009). In the Butana communal lands, grassland area was the prevailing LULC class. In contrast, shrub/tree cover which accounted for $18 \%$ in 1979 was only $10.8 \%$ in 2005 . Bare land showed a significant increase from $5.4 \%$ in 1979 to $22.7 \%$ in 1987 and to around one third of this site in 2005.

Overall, LULC classification accuracies have been estimated to be in the range from $79.78 \%$ to $96.89 \%$. Omission errors obtained were ranged between $0 \%$ and $13.79 \%$, while commission errors varied between $0 \%$ and 16.24\% (Table 4).

\section{Herders' perceptions of plant species changes}

According to respondents' observations, the quantity and quality of vegetation have deteriorated. Interviewed pastoralists mentioned 74 plant species, belonging to 30 plant families (Table 5). Figure 3 provides information on life forms and categories of change, i.e. disappeared, decreased and increased. The dominant life form is herbs followed by shrubs. However, herbs are mostly disappearing compared to other species. All plant species that have been classified by pastoralists as increasing are unpalatable species. On the other hand, all decreased species are palatable except Cymbopogon nervatus which is a main source for thatching. Woody material is the main building material in the region.

Informants among the 50 interviewed pastoralists identified the following reasons why plant species were disappearing or reducing (some respondents gave more than one reason, so answers are more than 100\%): declining rainfall amount (58\%), land clearance for agricultural expansion (34\%), overgrazing (26\%) and herbicide applications $(6 \%)$. The reasons given by the surveyed pastoralists for the increase of undesirable species are mainly mechanized agriculture (46\%), invaders from Ethiopia (30\%), changes in rainfall pattern (28\%) and herbicide applications (10\%).

\section{Pastoralist adaptations to rangeland degradation and climate change}

Concerning climate change, pastoralists said that they have witnessed that rains are falling late $(78 \%$ of respondents) and the rainy season is short (32\%). An elderly key informant remarked that:

'We used to have prolonged precipitation during the rainy season. We used to rearrange our camping locations to protect ourselves and livestock from early flooding of water courses. For the past few years, we rarely have such rainfall. 
Table 5 List of plant species mentioned by pastoral respondents (Dis disappear, Dec decrease, Inc increase)

\begin{tabular}{|c|c|c|c|c|}
\hline Scientific name & Family & Vernacular(s) & Trend & Life form \\
\hline Blepharis linariifolia & Acanthaceae & Seha (Begeil) & Dis & Herb \\
\hline Trianthema pentandra & Aizoaceae & Rabaa & Dec & Herb \\
\hline Achyranthes aspera & Amaranthaceae & Fakha & Inc & Grass \\
\hline Achyranthes muricata & Amaranthaceae & Lablab & Dec & Herb \\
\hline Calotropis procera & Asclepiadaceae & Usher & Inc & Shrub \\
\hline Sonchus cornutus & Asteraceae & Moleta (Malot) & Dec & Herb \\
\hline Xanthium brasilicum & Asteraceae & Rantouk & Inc & Herb \\
\hline Balanites aegyptiaca & Balanitaceae & Hegleg (Lalob) & Dec & Tree \\
\hline Cordia abyssinica & Boraginaceae & Gembeel & Dis & Tree \\
\hline Boswellia papyrifera & Burseraceae & Gafel (Eluban) & Dec & Tree \\
\hline Cassia senna & Caesalpinaceae & Sena Mekka (Senasena) & Inc & Herb \\
\hline Cassia tora & Caesalpinaceae & Kawal (Kola) & Inc & Herb \\
\hline Crateva adansonii & Capparaceae & Dabker & Dec & Shrub \\
\hline Boscia senegalensis & Capparaceae & Mokhet & Dec & Shrub \\
\hline Cadaba farinosa & Capparaceae & Sureh & Dis & Shrub \\
\hline Combretum aculeatum & Combretaceae & Shuhet & Dec & Shrub \\
\hline Combretum glutinosum & Combretaceae & Habeel & Dec & Tree \\
\hline Terminalia laxiflora & Combretaceae & Darot & Dec & Tree \\
\hline Commelina imberbis & Commelinaceae & Buwed (Ebrig Elfaki) & Dec & Herb \\
\hline Ipomoea carnea & Commelinaceae & Aweer & $\operatorname{lnc}$ & Shrub \\
\hline Ipomoea cordofana & Commelinaceae & Taber & Dec & Herb \\
\hline Astrochlaena lachnospermum & Commelinaceae & Um Galot & Inc & Herb \\
\hline Ipomoea sinensis & Commelinaceae & Hantot & Dec & Herb \\
\hline Merremia emarginata & Commelinaceae & Deriya & Dec & Herb \\
\hline Colocynthis sp. & Cucurbitaceae & Betig & Dec & Herb \\
\hline Cucumis sativus & Cucurbitaceae & Agoor (Himeid) & Dec & Herb \\
\hline Cephalocroton cordofanus & Euphorbiaceae & Dingel & Inc & Shrub \\
\hline Chrozophora oblongifolia & Euphorbiaceae & Tirba & Inc & Herb \\
\hline Ricinus communis & Euphorbiaceae & Kherwa & Inc & Tree \\
\hline Clitoria ternatea & Fabaceae & Lubia & Dis & Herb \\
\hline Crotalaria senegalensis & Fabaceae & Sufaree (Sufera) & Dec & Herb \\
\hline Crotalaria sp. & Fabaceae & Fagus & Dis & Herb \\
\hline Desmodium dichotomum & Fabaceae & Abu Areda & Dec & Herb \\
\hline Indigofera hochstetteri & Fabaceae & Shara & Dec & Herb \\
\hline Requienia obcordata & Fabaceae & Adan Elfar & Dec & Herb \\
\hline Sesbania pachycarpa & Fabaceae & Soreeb & Inc & Herb \\
\hline Tephrosia uniflora & Fabaceae & Um Regiga & Dec & Herb \\
\hline Zornia glochidiata & Fabaceae & Sheelnee Maak & Inc & Herb \\
\hline Ischaemum brachyatherum & Lamiaceae & Boos & Dec & Grass \\
\hline Ocimum basilicum & Lamiaceae & Rehan & Dec & Herb \\
\hline Schizachyrium exile & Lamiaceae & Himera & Dec & Herb \\
\hline Hibiscus esculentus & Malvaceae & Weka & Dis & Herb \\
\hline Acacia laeta & Mimosaceae & Alob Elkiter & Dec & Shrub \\
\hline Acacaia mellifera & Mimosaceae & Kiter (Burom) & Dec & Shrub \\
\hline
\end{tabular}


Table 5 List of plant species mentioned by pastoral respondents (Dis disappear, Dec decrease, Inc increase) (Continued)

\begin{tabular}{|c|c|c|c|c|}
\hline Acacia nubica & Mimosaceae & Laot & Dec & Tree \\
\hline Acacia senegal & Mimosaceae & Hashab & Dec & Tree \\
\hline Acacia seyal var. seyal & Mimosaceae & Taleh & Dec & Tree \\
\hline Acacia tortilis & Mimosaceae & Seyal & Dec & Tree \\
\hline Acacia nilotica & Mimosaceae & Sunut (Gared) & Dec & Tree \\
\hline Acacia polyacantha & Mimosaceae & Kakamot & Dis & Tree \\
\hline Dichrostachys cinerea & Mimosaceae & Kadad (Hergem) & Dec & Shrub \\
\hline Hyphaene thebaica & Palmae & Doom (Saaf) & Dis & Tree \\
\hline Hermania tigreensis & Philinidae & Karata & Dec & Herb \\
\hline Aristida adscensionis & Poaceae & Dembalab (Elgubash) & Dec & Grass \\
\hline Cenchrus biflorus & Poaceae & Haskaneet Khishin (Lesieg) & Dec & Herb \\
\hline Chloris gayana & Poaceae & Abu Efein & Inc & Herb \\
\hline Cymbopogon nervatus & Poaceae & $\mathrm{Nal}$ & Dec & Grass \\
\hline Cymbopogon proximus & Poaceae & Mahatreba & Dis & Herb \\
\hline Eragrostis ciliaris & Poaceae & Dees (Najela) & Dis & Grass \\
\hline Ophiuros papillosus & Poaceae & Ab Genger & Dis & Grass \\
\hline Oryza sp. & Poaceae & Riza & Dis & Grass \\
\hline Sorghum arundinaceum & Poaceae & Adar & Inc & Grass \\
\hline Sorghum purpureo-sericeum & Poaceae & Anees & Dec & Grass \\
\hline Portulaca oleracea & Portulacaceae & Rigla & Dec & Herb \\
\hline Ziziphus spina-christi & Rhamnaceae & Sider (Nabaeg) & Dec & Shrub \\
\hline Salix fragilis & Salicaceae & Sefsaf & Dec & Tree \\
\hline Salvadora persica & Salvadoraceae & Arak & Dis & Shrub \\
\hline Veronica sp. & Scrophulariaceae & Abu Moruwa & Dis & Grass \\
\hline Striga hermonthica & Scrophulariaceae & Buda & Inc & Herb \\
\hline Datura stramonium & Solanaceae & Sekaran & Inc & Herb \\
\hline Solanum dupuim & Solanaceae & Gebain & Dec & Herb \\
\hline Corchorus olitorius & Tiliaceae & Mulukheya (Khodra) & Dec & Herb \\
\hline Tribulus terrestris & Zygophyllaceae & Deresa & Dec & Herb \\
\hline
\end{tabular}

Though there are often erratic downpours these days, they do not last long'.

Delay in the flooding time of the rivers and watercourses was also noticed by respondents. Concerning the temperature, $94 \%$ of pastoralists mentioned that during the dry season (summer) time, there is a real increase in the day and $46 \%$ mentioned night temperature increases. According to their observations, the summer dry season is getting hotter, whereas the rainy season of winter is getting shorter and warmer. Some of them stated that there is almost no winter. They believe that rising temperature is the reason for endemic human diseases like Kala-azar (visceral Leishmaniasis) that recently appeared in the area. They also acknowledged (49\%) that in the last years there are strong dust storms prior to the rainy season.
Table 6 illustrates the adaptation measures that have been taken by pastoralists in response to their perceived climate change and range degradation. All pastoralists needed to rent cultivated land during summer time in order to feed their herds on the crop residue, i.e. sorghum stacks. Zero grazing is practiced mainly to feed newly born animals and their mothers near camping areas. Due to rangeland degradation and overgrazing in the camping area, $88 \%$ of respondents mentioned that they need to change their camping area more frequently and even within the same camping place, they needed to herd their flock for longer distances compared to the situation previously, i.e. in the 1980s.

Seventy-two per cent of interviewed pastoralists said that they have started to practice partial transhumance. This is an undesirable option, according to their judgment, which has been taken by poor pastoralists who 


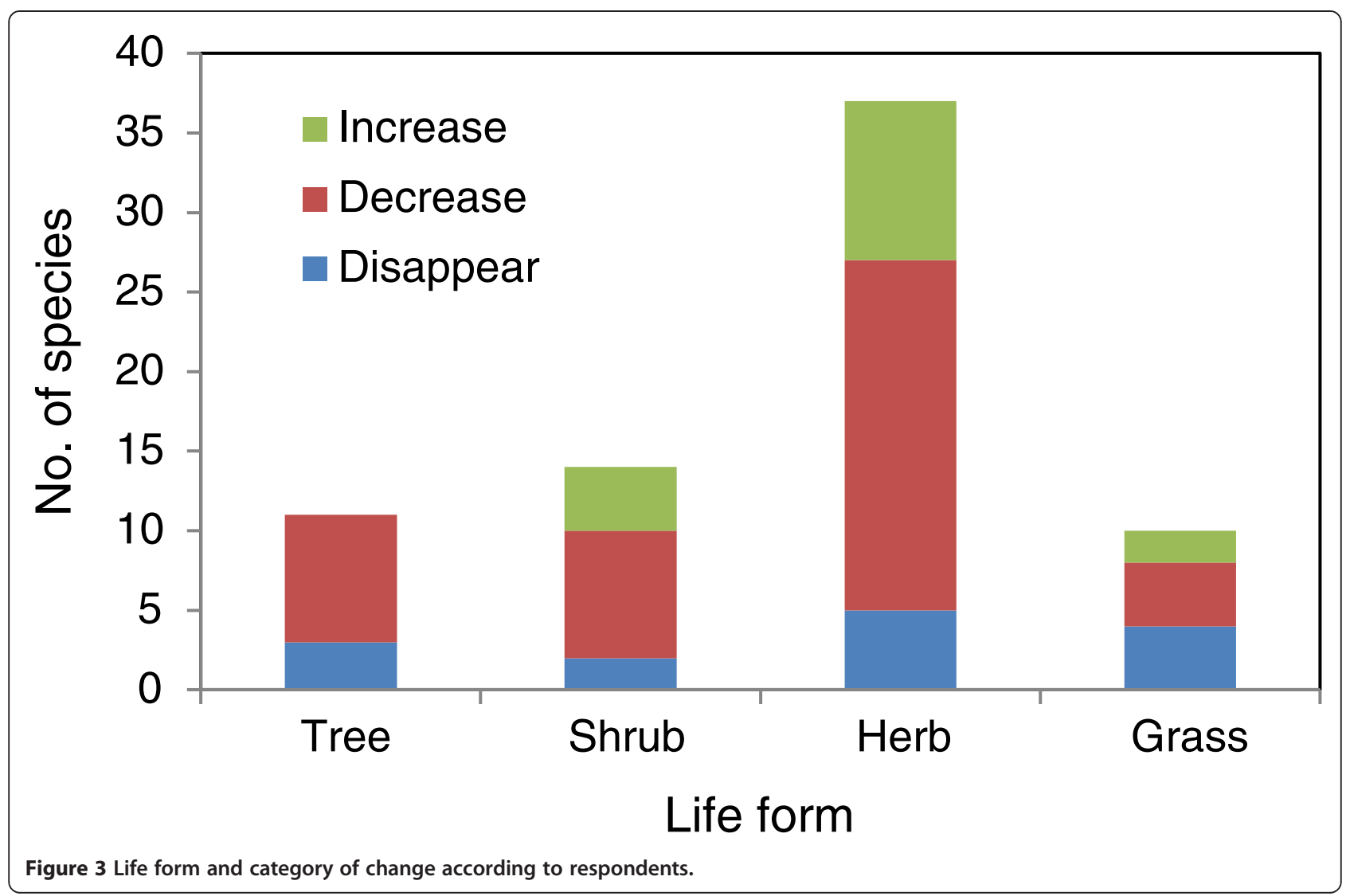

cannot remain as transhumant pastoralists and therefore settle or move elsewhere to join other groups. In such situations, family members establish small settlements in the vicinity of big villages, while young men accompany other groups with their remaining small herds and may at the same time work as hired labourers for rich pastoralists.

Although destocking has been a strategy followed by a considerable number of pastoralists (24\%), this is never a favoured option. One of the pastoralists said that:

'During the 2009 dry season, which was a bad season, I sold $50 \%$ of my herd in order to survive with the rest. I know some of my relatives who refused even to sell any animal from their herds but by the end of the season they lost the whole lot'.

The main reason for selling animals is to buy fodder in the form of crop residue and bring water from remote distances using tankers. Sixteen percent of respondents mentioned that in some seasons, in order to get pasture for their livestock, they need to cross the border into Ethiopia. Before doing so, however, they need to obtain some sort of agreement with local tribal leaders on the Ethiopian side. This is a practice that usually followed when there is scarcity of pasture. Factors impacting this

Table 6 Adaptation measures followed by transhumant pastoralists

\begin{tabular}{lcc}
\hline Adaptation measure & Number & Percent \\
\hline Renting agricultural land to benefit from crop residue & 50 & 100 \\
Utilizing more than one camping area and longer roaming distances & 44 & 36 \\
Partial transhumance and sedentarization & 18 & 72 \\
Destocking & 12 & 24 \\
Changing grazing time & 8 & 16 \\
Transboundary grazing (i.e. Ethiopia) & 5 & 10 \\
Supplementary water transporting using tankers & 1 & 2 \\
Do nothing &
\end{tabular}


practice are many, such as the changing relations between the two governments/states. Another factor is ethnicity, as this kind of agreement is not open for all ethnic groups from the Sudan side of the border. For example, in 2011 while the Lahaween had the chance to cross the border from Sudan to Ethiopia, it was not possible for other groups like the Bani Amer.

Ten percent of respondents need to transport supplementary water using tankers to water their animals. Such adaptations are only possible for wealthy pastoralists. During the field survey, we noted that many of the hafirs constructed by the Department of Animal Resources and Range to offer water for livestock were abandoned. This was because the hafirs were being damaged due to lack of care or an act purposely made by crop farmers in the neighbourhood to deny the opportunity for pastoralists' livestock to rest in the vicinity.

Although the climate variability and rangeland change have affected all components of the pastoral resources in the region, special attention has been given to the livestock migration routes. Throughout the field surveys and interviews, this was one of the most pressing issues facing pastoralism in the region. According to the pastoralists' judgment, water availability is the most serious problem along the routes. Many hafirs were blocked or destroyed purposely by crop farmers in the vicinity. Another problem concerning water availability is that local inhabitants of the Butana did not allow transhumant pastoralists to access hafirs around the villages. All these factors have put more pressure on pastoralists and made them shorten their trip along the routes. Competition over water resources has caused many conflicts between local inhabitants in the Butana and migrating pastoral groups. Under the conditions of climate change, such conflicts could easily develop. Another challenge on using the grazing routes is the encroachment of mechanized rain-fed agriculture onto the route zone. In some cases the cultivated areas totally block the route, which is done deliberately by large-scale farmers in order to hinder livestock moving in the vicinity of their land.

\section{Discussion}

\section{LULC change analysis}

The impact of LULC changes on grazing resources has been illustrated using multi-temporal satellite imagery and shown to provide a practical way for mapping and quantifying LULC changes in the three study areas. The decrease in natural vegetation in the three major grazing resources in Gadarif State is associated with a steady increase in bare land and/or cultivated area. As a consequence of increased exposure of land through removal of natural vegetation cover, the proportion of land prone to soil erosion increased. Therefore, it is critical to obtain current states of vegetation cover as a basis for initiating vegetation protection and restoration programmes (Egbert et al. 2002; He et al. 2005; Xie et al. 2008). In this respect, remote sensing technology offers a practical and economical means to study vegetation cover changes, especially over large areas (Langley et al. 2001; Nordberg and Evertson 2003; Sulieman 2010).

LULC change analysis showed in the dry season riverine camping areas that the reduction of natural vegetation and bare land area is due to agricultural expansion. Farmers mentioned that the expansion of mechanized farming in areas adjacent to Atbara and Rahad Rivers started during the early 1970s when the government began to give licenses to the private sector to take up mechanized farming in the area. Concerning the quality of vegetation cover, herders witnessed that evergreen to semi-evergreen tree species such Acacia nilotica, Acacia polyacantha and Combretum glutinosum which once prevailed in the area have been significantly reduced. Instead, invader species such as Ipomoea carnea have appeared along river banks. At the same time, the area along both rivers suffers from overgrazing due to the long stay of pastoralists in the area which annually ranges between six to seven months. El-Tayeb (1985) mentioned that overstocking around these permanent water supplies is serious, and the grazing value of the areas is mostly lost, i.e. become bare land. Using multi-temporal Landsat imagery from 1985, 1987 and 1990, Fadul et al. (1999) showed that clearance of natural vegetation due to expansion of rain-fed agriculture had exposed the soil surface to accelerated water erosion in areas along the Atbara River. The decrease or disappearance of certain plant species reduces vegetation cover and increases the exposure of soil surfaces to wind and water erosion, leading to more land degradation (Wezel and Haigis 2000).

Along the seasonal migration routes, the acute drop in natural vegetation that has been detected in LULC change analysis agrees with respondents' reports, when they acknowledge the problems facing the routes. Bare land is a minimal LULC class in this study location. This is due to the fact that farmers try to cultivate all available land and do not leave un-cultivated land along the routes, so as to minimize any roaming of animals around their farms. Therefore, conflicts between farmers and pastoralists mainly occur in the post-rainy season along nomadic corridors during the pastoralists' movement towards their dry season grazing areas (WISP 2007). Sulieman and Elagib (2012) showed that livestock mobility is being increasingly challenged. They found that land degradation and blocking of animal routes are one of the paramount factors that led to pastoralist sedentarization, urbanization and the breakdown of the traditional pastoralist livelihood system. In addition to loss of grazing land, agricultural expansion has also blocked livestock migratory routes between dry and wet season pastures, and between the herds and their daily watering points 
(Sulieman 2013; UNEP 2007). The situation is more or less similar in other countries in the Horn of Africa where commercial agriculture is reported as threatening the existence of livestock migration routes (Flintan 2011).

Although grassland is the prevailing LULC in the Butana area, field visits and interviews with herders clearly showed their qualitative degradation in terms of species composition. Domination of unpalatable species such as Cymbopogon proximus and Cassia senna has been observed in many parts of this site. The domination of unpalatable plant species could be attributed to the communal grazing system which has been adopted in the area since 1971 (Akhtar 1993). Herders stated that species of higher nutritive value such as Ipomoea sinensis and Blepharis linariifolia have almost completely disappeared. They considered that open access and uncontrolled grazing are the principal causes of overgrazing and land degradation. Communal grazing lands required individual users to group together to determine the optimal number of total livestock to be allowed on the range and to distribute grazing rights among all users so that the total number of livestock does not exceed carrying capacity. However, experience has shown that in the absence of strong institutional controls over individual stocking decisions, it is difficult to achieve this kind of co-operative outcome (ILRI 1995).

Shrub/tree cover is rapidly decreasing in Butana. At the same time, palatable woody species such as Acacia tortilis, Maerua crassifolia and Ziziphus spina-christi are disappearing due to heavy browsing especially in the vicinity of settlements and where sufficient water supplies are available in the khors/valleys. It is clear that selective grazing in these khors/valleys has led to a severe vegetation transformation. Woody vegetation currently dominates in depressions and khors/valleys, consisting mainly of Acacia mellifera with intermittent occurrences of unpalatable species like Acacia nubica, Calotropis procera and Capparis decidua. Akhtar (1993) mentioned that the disorganized use of grazing lands by all ethnic groups in the Butana has led to a rapid spread of desertification since the 1970s, accelerated further by the droughts of the 1980s.

Besides intensive overgrazing on some vegetation zones, the recent introduction of mechanized farming to the area has been quoted by respondents as one of the main factors leading to the significant increase of bare land in the Butana area. Mechanical working of the shallow soils, using tractors and wide-level discs, has led to mechanical soil damage, and in many cultivated areas, gravels appeared on the top soil due to fluctuation of rain; after a few seasons of cultivation, the land is abandoned. Holter (1994) mentioned that deterioration in the woody vegetation area is due to drought, extensive use of trees for fuel and expansion of the rain-fed cultivated area. Butana recently experienced severe drought in 1984, 1990 and 2000 (Elhag and Walker 2009). Nevertheless, the increasing scarcity of virgin land in the southern part of the state has resulted in largescale mechanized farming being illegally pushed northwards until it is now just into the heart of the Butana (Babiker 2011). It should be emphasized that the expansion of cultivation is one of the major forces driving land cover change in the whole Sudano-Sahelian zone of Africa (Hiernaux and Turner 2002), and the Butana is part of that zone.

Local knowledge of changes in plant species composition Local communities harbour important information on valuable plants and vegetation dynamics; their knowledge is fundamental for management strategies aimed at sustainable use and conservation of natural vegetation (Lykke 2000). This is especially the case when other historical and ecological information is not available (Sulieman et al. 2012). Pastoralists in the study area mentioned a comprehensive list of plant species in the region, providing detailed descriptions that include, among others, life form and change trend (Table 5). They are aware of the environmental changes taking place in their surroundings. It is known that local knowledge-based management strategies could ensure a focus on the species and vegetation types that are most valuable to local communities (Sulieman et al. 2012). In the grazing lands, monitoring of biodiversity would therefore be more effective if responsible range departments assessed biodiversity and established monitoring regimes based on scientific and indigenous knowledge (Oba et al. 2008; Lykke et al. 1999; Angassa and Oba 2008). Considering that pastoralists are frequently observing and exploiting the local environment and have in-depth knowledge of the traditional methods of rangeland assessments, their contribution to range management is expected to be more efficient than policies imposed by governments (Mills et al. 2002; Oba and Kaitira 2006).

Based on their annual movements, we would expect that pastoralists explore all available grazing resources across the region. The reasons given by pastoralists for the decline in vegetation species number ranged from climatic to anthropogenic factors. The herders elucidate the changes of herbaceous species in terms of the disappearance and decrease of desirable species. On the other hand, important information gleaned from discussions with herders explained some reasons beyond the increase of unpalatable plant species. According to herders, the amount and timing of precipitation were the most important determinants of changes in plant species. They see factors like changes in rainfall pattern and herbicide applications playing significant roles in this process of change. For example, late and erratic rainfall is not favourable for palatable species, whilst it is suitable for emergence of unpalatable species. It is 
widely perceived by herders that Hibiscus esculentus, which is one of the most edible plants in the region, is disappearing due to wide application of herbicide. At the same time, they emphasize that herbicide application is the reason why some unpalatable species such as Xanthium brasilicum and Datura stramonium dominate. According to the herders, as others have also shown (Oba et al. 2008), useful plant species represent favourable range condition indicators, while the undesirable species reflect deteriorating trends, from the herders' perspective.

Herbicide application for rain-fed agriculture was introduced recently to the area in the 2000s. Before the introduction of herbicides, weeding was practiced manually and considered to be the most costly operation in the crop production budget. According to crop farmers' perceptions, herbicide application is more economical than the expensive labourious hand weeding, especially for areas heavily infested by weeds (Sulieman and Buchroithner 2009). Currently, however, farmers are applying selective herbicides which are affecting weed species composition. For example, it is not possible to control some species such as wild sorghum because of its close genetic constituent with sorghum.

The evidence from East Africa provided by Oba and Kaitira (2006) suggests that descriptions of landscape degradation in terms of loss of grazing value for the livestock might be more relevant than a general statement about rangeland degradation associated with pastoral land use. Their findings recommend reconsidering descriptions of land degradation in terms of grazing preference of livestock, as opposed to plant species composition alone. As reported by Fernandez-Gimenez (2000), herders' detailed knowledge of plants, including changes in pasture conditions across space and over time, clearly shows a strong understanding of ecological relationships and processes.

\section{Pastoralist adaptations to rangeland degradation and climate variability}

It is important to stress that the pastoral resources in the region are under pressure from human activities as well as possibly suffering from impacts of climate change, noted in meteorological observations recently analyzed by Sulieman and Elagib (2012). However, the objective of this study is to discuss the issue of both land degradation and climate variability and their relation to each other. Climate variability is one among a number of important drivers of change in the region. It has both direct and indirect impacts on the ecological and socioeconomic components of the grazing resources at different spatial and temporal scales. Herders' perceptions about a changing climate appeared to be in accordance with the recent patterns (Sulieman and Elagib 2012). The present accelerated rate of climate variability has led to more difficulty in predicting rangeland productivity and changes in the availability of water and grass resources, making pastoral production more uncertain than ever before. This, coupled with conflict and other socioeconomic disadvantages, means that pastoralists are less able to cope with these changes and they suffer more.

Crop residues from mechanized agricultural land represent the supplementary forage sources for the livestock of all respondents. The present findings are consistent with the results of Glover (2005), who reported that crop residues formed a significant portion of the livestock diets in the study area. Currently, the area under mechanized cultivation is estimated to be 4.2 million ha (MFC 2012). The destructive role played by mechanized rain-fed agriculture as a main factor for natural vegetation clearings in the region (Sulieman and Buchroithner 2006) and the trade-off due to meeting gaps in forage supply for pastoralist livestock that result from mechanized agriculture is an issue that needs to be carefully examined. According to SKAP (1992), although natural grazing land and forage supplies in Gadarif area have been depleted in both quantity and quality due to recent changes in land use, they are now supplemented by livestock feed sources provided by arable farms. Crop residues, fallow fields and failed crops of the area now provide four fifths of the available grazing and forage sources of the entire area. It is known that raw crop residue has a low nutritive value for livestock feeding, compared to natural pastures (Owen and Jayasuriya 1989). However, crop residue could be upgraded to improve its intake and digestibility by using low-technology treatments such as ammonia generated from fertilizer urea (Sundstol et al. 1978). In recent years, pastoralists need to pay in order to get access to crop residue in the agricultural land. Previously, local orders were annually issued which stipulated the latest date for harvest, after which pastoralists were free to enter the cultivated area and graze. The British colonial government strictly enforced these regulations, mainly through the native administrators who guarded the domain of pastoral activity (Shazali and Ahmed 1999).

Mobile livestock grazing is a traditional mechanism developed by herders to cope with changes induced by climate variability in the availability of water and fodder at different places and times. In recent years, however, pastoralists have shortened their pattern of mobility, to be more frequent movements, especially during the dry season. The reason cited by pastoralists is to seek enough fodder and water for their herds. Therefore, some pastoralists have adopted partial sedentarization, by leaving children and elderly people in settled locations, in order to make movement practical and easier. These pastoralist groups are expected to benefit from having permanent settlements, where they can more easily access services such as health and education. However, they do not intend to abandon their 
traditional way of keeping animals. Many have developed an advanced form of transhumance, as can be seen among the Rashaida group in eastern Sudan and the Rufa'a al Hoi group in Blue Nile State (Ahmed 2009). The movements of both the Rashaida and the Rufa'a al Hoi are no longer curtailed by the lack of water in places where grazing is available for their animals. They have developed a system of using tankers to take water to the animals where they can have enough grass for grazing. During this period, parts of the families are settled in places where they can have access to necessary services. This is a form of intensifying production.

Destocking is a strategy followed by many pastoralists in order to cope with climate shock and to provide money for purchasing crop residues. However, the ongoing destocking process has threatened and impoverished large numbers of small-owner pastoralists. This agrees with findings of other previous researchers. Thus, Morton (1987) and Shazali (1993), studying the Lahaween in eastern Sudan, have argued that they have been considerably impoverished as their pastoral pursuits have declined. This prospect causes considerable concern, since the impoverished do not have alternatives to maintain their livelihoods within the present structures of the economy (UNDP 2006). Livestock rustling during cross-border livestock movements to Ethiopia is also causing destocking for some pastoralists. Sixteen percent of respondents mentioned that in some seasons, in order to get pasture for their livestock, they need to cross the border into Ethiopia. Before deciding to cross the border, they need to attain agreement with local tribal leaders on the Ethiopian side. However, transboundary conflicts between Sudan and Ethiopia are chronic, with a long and complex history (Sulieman et al. 2011).

\section{Challenges to adaptation}

Pastoralist adaptations have been weakened by both internal and external pressures. This study has revealed that pastoralists have considerable knowledge and experience in dealing with climatic variability. However, various other factors, such as their marginalization in decision-making concerning resource use and their lack of education and other basic services, restrict their possibilities to adapt. The pastoralists are being marginalized not only by being pushed out of their traditional lands but also through neglect in developing their human and animal capital. Our survey showed that the state failed to provide needed services such as education. Among the 50 interviewed pastoralists, 44 (88\%) are illiterates. When interviewed, leaders of the Herders' Union said that mobile education is thought to be costly, according to the office of mobile education within the Gadarif State Ministry of Education.

In an exploratory study in Ethiopia and Niger of pastoralists' responses to perceived climate change (GebreMichael et al. 2011), it was mentioned that the root causes of pastoralists' vulnerability to climate change lie in their marginalization in decision-making and in unfavourable government policies. In attempting to address adaptation to climate change, these authors recommend that primary attention should be given to these root causes of vulnerability, not only focusing on technical adaptation to climate change. Otherwise, more immediate challenges to the livelihoods of pastoralist communities could exacerbate the vicious cycle of impoverishment and contribute to undermining their survival capacity. Ahmed (2012) has stated that numerous attempts to address the issue of nomadic pastoral groups in Sudan's planned development have had no conclusive or positive results and in many cases has led to the further marginalization of these groups.

\section{Conclusions}

Based on LULC change analysis using multi-temporal satellite imagery, combined with local knowledge from pastoralists, this study has quantitatively and qualitatively analyzed the spatial-temporal changes from 1979 to 2009 on grazing resources in Gadarif, Sudan. The information generated from the LULC pattern of the study area is expected to be of immense help in formulating policies and programmes required for development and planning in the pastoral sector. The recorded changes have disrupted the traditional transhumance systems, resulting in greater grazing pressure. Despite the changes in traditional patterns of land use and the acknowledgment by policymakers of land grabbing as a major impediment to improving livestock productivity and natural resources management, state policymakers in Gadarif did not consider the issue of land degradation to be a top priority. Instead of attempting to rehabilitate, upgrade or modernize the pastoral system, policymakers and planners think of settling pastoralists.

One of the adverse consequences of the rapid expansion of mechanized agriculture in the region is loss of biodiversity due to natural vegetation clearance. This leads to high rates of species disappearance as well as extinction of many important fodder plants in the region. Similarly, some agricultural practices such as herbicide application by crop farmers are leading to changes in natural species composition. In fact, it is known that the long-term effect of applying herbicide to control weeds can reduce species diversity and lead to the emergence of new invader plants (Ortega and Pearson 2011; Duary et al. 2012).

Assessment of changes in grazing resources in Gadarif has shown that the current patterns are going to threaten the existence of pastoralists in the region. Pastoralists find that encroachment of mechanized cultivation schemes on their grazing routes is one major problem that they face. The expansion of such schemes deprives pastoralists of their resting place during their dry season movement. 
Furthermore, it also denies them access to hafirs meant for watering their animals and forces them to compete with settled villagers for access to land and water, which sometimes leads to conflicts.

Pastoralists have to make the difficult choice of destocking in order to buy crop residues and bring water for their herds, using tankers in order for them to continue their pastoral system of livelihood. Those who avoid such a choice may, over time, risk losing their herds. However, even this choice is becoming partly difficult to achieve, since some of the mechanized scheme owners have started to invest in raising herds and using their crop scheme residues to feed their own livestock. One more choice that pastoralists make is to cross the borders into Ethiopia where there are available grazing sources. To do so, they need to make arrangements with the local leadership on the Ethiopian side. This could be resolved if a soft border is agreed upon between Gadarif state and the neighbouring Ethiopian administration.

Discussing the issues facing pastoralists in the region, it became clear that they are marginalized compared to the settled population. They are not offered access to education, nor are they able to make or influence decisions about land and water access that impact their daily life. They do their best to adapt to the changing situations using their indigenous knowledge. However, such knowledge needs to be interlinked with scientific knowledge if sustainable development and modernization of the sector are the goal. The present study shows that it is possible by using remote sensing and local indigenous knowledge to have a better understanding of development issues, in planning for the benefit of the local population, the federal state and the country as a whole.

\section{Competing interests}

The authors declare that they have no competing interests.

\section{Authors' contributions}

HMS designed the project, performed the statistical analysis and drafted the manuscript. AGMA participated in its design, coordination of the project and drafted the manuscript. Both authors have read and approved the final manuscript.

\section{Authors' information \\ HMS is Director of the Centre for Remote Sensing and Geographical Information Systems and Associate Professor at the Faculty of Agricultural and Environmental Sciences of the University of Gadarif, Sudan. AGMA is Professor of Social Anthropology at the University of Khartoum, Professor of Development Studies at Ahfad University for Women and Affiliated Associated Senior Researcher at Chr. Michelsen Institute, Norway.}

\section{Acknowledgements}

The financial support provided by East Sudan Research Group is gratefully acknowledged. The kind assistance of the Range Department in Gadarif is also acknowledged. Special thanks also go to Mr. Ammar A. Suliman for joining the field work. The authors thank Gunnar M. Sørbø for his comments on a draft of this paper, as well as those from anonymous reviewers.

\section{Author details}

${ }^{1}$ Centre for Remote Sensing and Geographical Information Systems, Faculty of Agricultural and Environmental Sciences, University of Gadarif, P.O. Box 449, 32211 Gadarif, Sudan. ${ }^{2}$ Department of Social Anthropology, University of Khartoum, Khartoum, Sudan.

Received: 25 March 2013 Accepted: 15 July 2013

Published: 4 October 2013

\section{References}

Ahmed, AE. 1989. Man-made forests. In The forests of the Sudan, ed. KH Badi, AE Ahmed, and MS Bayoumi, 33-141. Khartoum: Agricultural Research Council.

Ahmed, AGM. 2009. Transforming pastoralism: A case study of the Rufa'a Al Hoi ethnic group in the Blue Nile State, Sudan. Nomadic People 13(1): 113-133.

Ahmed, AGM. 2012. Pastoral development paradigms - The case of Sudan, vol. Issues (2-3), 13-27. Discourse, a journal published by Peace Research Institute, University of Khartoum.

Akhtar, M. 1993. Desertification in the Butana. Geo J 31(1): 41-50.

Angassa, A, and G Oba. 2008. Herder perceptions on impacts of range enclosures, crop farming, fire ban and bush encroachment on the rangelands of Borana, southern Ethiopia. Human Ecol 36: 201-215.

Babiker, M. 2011. Mobile pastoralism and land grabbing in Sudan: Impacts and responses. International conference on the future of pastoralism. 21-23 March 2011. Institute of Development Studies, University of Sussex and Feinstein International Center of Tufts University. http://www.futureagricultures.org/publications/publication-by-theme/climate-change\#.UfRcW1EEQw. Accessed 10 March 2012.

Biro, K, B Pradhan, M Buchroithner, and F Makeschin. 2011. Land use/land cover change analysis and its impact on soil properties in the northern part of Gadarif region, Sudan. Land Degradation Dev 24(1): 90-102. doi:10.1002/ Idr.1116.

CBS (Sudan Central Bureau of Statistics). 2012. Fifth Population and Housing Census.. Government of Sudan, http://www.cbs.gov.sd/RESULT/Priority\% 20English.xls (accessed 23 July 2012).

Duary, B, A Hossain, DC Mondal, and A Mukherjee. 2012. Long term effect of herbicides on weed shift and yield of rice-yellow sarson system in the lateritic soil of West Bengal, India, Pakistan. J Weed Sci Res 18: 757-766.

Egbert, SL, S Park, KP Price, Y Lee, J Wu, and MD Nellis. 2002. Using conservation reserve program maps derived from satellite imagery to characterize landscape structure. Computers Electron Agri 37: 141-156.

Elhag, M, and S Walker. 2009. Impact of climate variability on vegetative cover in the Butana area of Sudan. African J Ecol 47(1): 11-16.

El-Tayeb, G. 1985. The Gedarif study area. Khartoum: Institute of Environmental Studies, Khartoum University.

Fadul, HM, AA Salih, IA Ali, and S Inanaga. 1999. Use of remote sensing to map gully erosion along the Atbara River, Sudan. Int J Appl Earth Observation Geoinform 1(3-4): 175-180.

Fahey, D. 2007. The political economy of livestock and pastoralism in Sudan. IGAD LPI Working Paper No. 06-08. Addis Ababa: IGAD Livestock Policy Initiative.

Feng, Y, Q Lu, T Tokola, H Liu, and X Wang. 2009. Assessment of grassland degradation in Guinan county, Qinghai Province, China, in the past 30 years. Land Degradation Dev 20: 55-68.

Fernandez-Gimenez, ME. 2000. The role of Mongolian nomadic pastoralists' ecological knowledge in rangeland management. Ecol App 10(5): 1318-1326.

Flintan, F. 2011. "Broken lands, broken lives?" Causes, processes and impacts of land fragmentation in the rangelands of Ethiopia, Kenya and Uganda. Nairobi: REGLAP.

GebreMichael, Y, S Magagi, W Bayer, and A Waters-Bayer. 2011. More than climate change: Pressures leading to innovation by pastoralists in Ethiopia and Niger. International conference on the future of pastoralism. 21-23 March 2011. Institute of Development Studies, University of Sussex and Feinstein International Center of Tufts University. http://www.futureagricultures.org/publications/publication-by-theme/climate-change\#.UfRcW1EEQw. Accessed 10 March 2012.

Glover, EK. 2005. Tropical dryland rehabilitation: Case study on participatory forest management in Gedaref, Sudan. Helsinki, Finland: PhD dissertation. Faculty of Agriculture and Forestry of the University of Helsinki.

He, C, Q Zhang, Y Li, and P Shi. 2005. Zoning grassland protection area using remote sensing and cellular automata modelling-A case study in Xilingol steppe grassland in northern China. J Arid Environ 63: 814-826. 
Hiernaux, P, and MD Turner. 2002. The influence of farmer and pastoralist management practices on desertification processes in the Sahel. In Global desertification: Do humans cause deserts? ed. JF Reynolds and MD StaffordSmith, 136-148. Berlin: Dahlem University Press.

Holter, U. 1994. The importance of cultural background and sedentarization in patterns of behavior. The example of the Miheidat (Shurkriya) in the central Butana (Sudan). Animal Res Dev 39: 55-66.

ILRI (International Livestock Research Institute). 1995. Livestock policy analysis. ILRI training manual 2, 264. Nairobi: ILRI.

Lambin, EF, HJ Geist, and E Lepers. 2003. Dynamics of land-use and land-cover change in tropical regions. Ann Rev Environ Res 28: 205-241.

Langley, SK, HM Cheshire, and KS Humes. 2001. A comparison of single date and multitemporal satellite image classifications in a semi-arid grassland. J Arid Environ 49: 401-411.

Lykke, AM, B Fog, and JE Madsen. 1999. Woody vegetation changes in the Sahel of Burkina Faso assessed by means of local knowledge, aerial photos, and botanical investigations. Geografisk Tidsskrift Danish J Geography 2: 57-68.

Lykke, AM. 2000. Local perceptions of vegetation change and priorities for conservation of woody-savanna vegetation in Senegal. J Environ Manag 59: 107-120.

Manger, L. 2001. Pastoralist-state relationships among Hadendowa Beja of eastern Sudan. Nomadic Peoples 5(2): 21-47.

MFC (Mechanized Farming Corporation). 2012. Annual report. Gadarif: Ministry of Agriculture.

Mills, D, R Blench, B Gillam, M Martin, G Fithardinge, J Davies, S Campbell, and L Woodhams. 2002. Rangelands: People, perceptions and perspectives. In Global rangelands: Progress and prospects, ed. AC Grice and KC Hodgkinson, 43-54. Oxon: CAB International.

Morton, JF. 1987. The pastoralists of the Showak Area, Sudan. Khartoum: Report for SCF/USA

Nordberg, ML, and J Evertson. 2003. Vegetation index differencing and linear regression for change detection in a Swedish mountain range using Landsat TM and ETM + imagery. Land Degradation Dev 16: 139-149.

Oba, G, and LM Kaitira. 2006. Herder knowledge of landscape assessments in arid rangelands in northern Tanzania. J Arid Environ 66: 168-186.

Oba, G, P Byakagabar, and A Angassa. 2008. Participatory monitoring of biodiversity in east African grazing lands. Land Degradation Dev 19: 636-648

Ortega, YK, and DE Pearson. 2011. Long-term effects of weed control with picloram along a gradient of spotted knapweed invasion. Rangeland Ecol Manage 64(1): 67-77.

Owen, E, and MCN Jayasuriya. 1989. Use of crop residues as animal feeds in developing countries. Res Dev Agri 6(3): 129-138.

Reed, MS, AJ Dougill, and TR Baker. 2008. Participatory indicator development: What can ecologists and local communities learn from each other? Ecol App 18(5): 1253-1269.

Richards, JA, and X Jia. 2005. Remote sensing digital image analysis, 4th ed. Berlin: Springer.

Ruelland, D, F Levavasseur, and A Tribotte. 2010. Patterns and dynamics of landcover changes since the 1960s over three experimental areas in Mali. Int J App Earth Observ Geoinform 12S: S11-S17.

SCC (Soil Conservation Committee). 1944. The report of the Soil Conservation Committee. Khartoum: Sudan Government.

Shazali, S. 1993. Pastoral vulnerability, environmental degradation and state policy: The case of south Kassala, Sudan. DebreZeit, Ethiopia: Paper IVth OSSREA congress on the global nature of the environmental crisis and its interrelationship with development: Africa's plight. August 9-12.

Shazali, S, and AGM Ahmed. 1999. Pastoral land tenure and agricultural expansion: Sudan and the Horn of Africa. Berkshire, UK: DFID workshop on land rights and sustainable development in sub-Saharan Africa at Sunningdale Park Conference Centre. 16th-19th February 1999.

Sidahmed, AE. 1996. The rangelands of the arid/semi-arid areas: Challenges and hopes for the 2000s. The international conference on desert development in the Arab Gulf countries, 23-26. Kuwait: KISR. March 1996.

SKAP (Southern Kassala Agricultural Project). 1992. Land use survey report (main report). Khartoum: Government of Sudan.

Stringer, LC, and MS Reed. 2007. Land degradation assessment in southern Africa: Integrating local and scientific knowledge bases. Land Degradation Dev 18: 99-116.
Sulieman, HM. 2008. Mapping and modeling of vegetation changes in the southern Gadarif Region, Sudan, using remote sensing - Land-use impacts on biophysical processes. Dresden: TUDpress.

Sulieman, HM. 2010. Expansion of mechanised rain-fed agriculture and landuse/land- cover change in the Southern Gadarif, Sudan. Afr J Agric Res 5: 1609-1615.

Sulieman, HM. 2013. Land grabbing along livestock migration routes in Gadarif state, Sudan: Impacts on pastoralism and the environment. LDPI Working Paper 19. The Hague: The Land Deal Politics Initiative, The International Institute of Social Studies, Erasmus University Rotterdam.

Sulieman, HM, and MF Buchroithner. 2006. Assessment of natural vegetation clearing and re-growth in southern Gadarif Sudan using change vector analysis based on remote sensing and field data. Enschede, The Netherlands: ISPRS Commission VII mid-term symposium "Remote Sensing: From Pixels to Processes".

Sulieman, HM, and MF Buchroithner. 2009. Degradation and abandonment of mechanized rain-fed agricultural land in the southern Gadarif region, Sudan: The local farmers' perception. Land Degradation Dev 20(2): 199-209.

Sulieman, HM, and NA Elagib. 2012. Implications of climate, land-use and landcover changes for pastoralism in eastern Sudan. J Arid Environ 85: 132-141.

Sulieman, HM, IA Abaker, and SA Elbarbari. 2011. Livelihood vulnerability among climate induced-immigrant farmers in Gadarif state, Sudan: Perceptions and adaptation measures. Nairobi, Kenya: AAS, ICIPE and TWAS conference on "Climate Change and Food Security: The Road for Africa", 10-12 November 2011. Conferences proceedings.

Sulieman, HM, MF Buchroithner, and MM Elhag. 2012. Use of local knowledge for assessing vegetation changes in the southern Gadarif region, Sudan. African J Ecol 50(2): 233-242.

Sundstol, F, E Coxworth, and DN Mowat. 1978. Improving the nutritive value of straw and other low quality roughness by treatment with ammonia. World Animal Rev 26: 13-21.

Tamador, AKA. 2010. The Lahawiyin: Identity and history in a Sudanese Arab tribe. Durham theses, Durham University. Durham E-Theses. http://etheses. dur.ac.uk/707/. Accessed 12 May 2012.

UNDP. 2006. Share the land or part the nation: The pastoral land tenure system in Sudan (STUDY 3) NDP in Sudan. Khartoum, Sudan. http://www.sd.undp. org/publications/rrbc/Share\%20The\%20Land\%200r\%20Part\%20The\% 20Nation.pdf. Accessed 20 June 2012

UNEP (United Nations Environment Programme). 2007. Sudan post-conflict environmental assessment. Nairobi: UNEP.

Wezel, A, and J Haigis. 2000. Farmers' perception of vegetation changes in semiarid Niger. Land Degradation Dev 11: 523-534.

WISP (The World Initiative for Sustainable Pastoralism). 2007. Sudan's Policy towards Traditional Livestock Migration Routes (Darfur States Case). http://cmsdata.iucn. org/downloads/sudan_policy_study_report.pdf (accessed 03 October 2012).

Xie, Y, Z Sha, and M Yu. 2008. Remote sensing imagery in vegetation mapping: A review. J Plant Ecol 1(1): 9-23.

Yiran, GAB, JM Kusimi, and SK Kufogbe. 2012. A synthesis of remote sensing and local knowledge approaches in land degradation assessment in the Bawku East District, Ghana. Int J App Earth Observ Geoinform 14: 204-213.

Zheng, D, DO Wallin, and Z Hao. 1997. Rates and patterns of landscape change between 1972 and 1988 in the Changbai mountain area of China and North Korea. Landscape Ecol 12: 241-254.

doi:10.1186/2041-7136-3-22

Cite this article as: Sulieman and Ahmed: Monitoring changes in pastoral resources in eastern Sudan: A synthesis of remote sensing and local knowledge. Pastoralism: Research, Policy and Practice 2013 3:22. 